\title{
The Role of the U.S. in Terrorism in the Middle East
}

\author{
Sadegh Piri ${ }^{1} \&$ Ali Yavar Piri ${ }^{2}$ \\ ${ }^{1}$ Faculty of Law and Political Science, Allameh Tabatabaei University, Tehra, Iran \\ ${ }^{2}$ Department of Political Science, Islamic Azad university, Tehran, Iran \\ Correspondence: Sadegh Piri, Faculty of Law and Political Science, Allameh Tabatabaei University, Tehra, Iran. \\ E-mail: piry_sadegh@yahoo.com
}

Received: February 14, 2016 Accepted: April 5, 2016 Online Published: April 27, 2016

doi:10.5539/jpl.v9n3p31 URL: http://dx.doi.org/10.5539/jpl.v9n3p31

\begin{abstract}
Terrorism is a widespread phenomenon with a long history reflecting broad and contradictory points of view. This phenomenon has wide aspects occurring in different ways which is not belonging to a specific geographical region. Though, undoubtedly, the prevalence of terrorism in a particular area, e.g. the Middle East indicates the true potential of this given region for emergence and existence of this phenomenon. This paper tries to show the role of foreign countries, i.e. the U.S., besides exploring regional factors contributing to development and evolution of terrorism in the Middle Eater.
\end{abstract}

Keywords: terrorism, Middle-East, United States, fundamentalism

\section{Introduction}

Political and geographical structure of the Middle East is the result of partitioning the Ottoman and Persian Empire. In fact, the defeat of the Germany, Italy and Ottoman in the World war One formed new structure of the Middle East. The Political structure of the region underwent changes after the World War Two again and many regional countries win their independence as tendencies to nationalism and anti-colonialism dramatically rised among them and they established their independent governments by breaking up colonial relationships.

There are a wide diversity of questions concerning to factors contributing to development and growth of terrorism in the Middle East, to name a few: whether religious schism and misunderstanding of religious doctrine give rise to extremism and, in turn, growth of ideological terrorism in the Middle East or it is because of tribal and ethnic conflicts? How important the role of ethnic diversity is in provoking disagreement between the regional countries? Does allocation of hefty military budget by the regional countries result in an arm race and, in turn, a security dilemma and growth of militarism in the Middle East? But the main question in this paper is addressing the importance of the U.S. role in emergence of terrorism in the Middle East. This paper tries to appreciate the role of The U.S. as being a catalyst and external factor in realizing the potential of the Middle East to become a suitable region for terrorist activities.

\section{Methodology}

Terrorism is an elusive concept in the international context facing a sort of "crisis" in its definition and scope due to the complexity of its notion and examples. Josef Nay does not recognize terrorism as a new phenomenon and believes that it is deeply rooted in the political and international history. In his opinion, terrorism is a kind of conflict defined as a deliberate and public attack against innocent people for purpose of inspiring fear and terror.

Alex Schmitt and J. Albert Jungman in their research ordered by the U.S. military put forward 109 definitions, including 22 different sections, for the terrorism.

Mahathir Mohamad, the Malaysia ex-prime minister, defines the terrorism as the whole attacks made against civilians.

As mentioned before, there are many definitions provided for the terrorism though they share some common attributes indicating their similarities: 1) employing violence or, at least, threatening to do so which is regarded as fundamental element of all terrorist activities, 2) committing violence for political purposes: this classification is, inevitably, made to draw a distinction between terrorism and other violent activities and crimes, 3) civilians are the targets of terrorist threats and damages. 
There are local and international aspects to take into account while analyzing factors contributing to formation of the fundamentalism and terrorism in the Middle East. The former, as mention before, is the hidden potentials of the Middle East for the terrorism and the latter that is also called external aspects refers to polices adopted by the Western countries, and the U.S. in particular, that results in emergence of terrorism in this given region. This aspect is addressed in the next section.

\section{Regional Factors}

There are, undoubtedly, many factors in the Middle East making it a highly potential region for terrorism. This article tries to address the most important one, namely ethnic and schism conflicts and misconception of religious principles, structural underdevelopment among the regional countries, border conflicts, ethnic and religious diversity and allocation of hefty military budgets provoking the arm race in the Middle East.

\section{Border Conflicts}

Geographical and geopolitical situations are among the most significant factors in specifying and pursuing political objectives. As stated by Haws Hoffer, geopolitics shows how geographical factors determine political decisions. Borders, also, play a key role in forming political and economic relationship between countries. But a few border lines have been determined based on mutual agreement between the countries in the Middle East and the issue of border has been always the subject of conflict in this region. The principal point here is that significance of the geopolitics of the region along with prolonged border conflict are among the contributing factors to tension, unrest and violence between the regional countries which will be further discussed in below.

It can be claimed that the border conflicts in the Middle East has arisen from dissolution of the Ottoman Empire at the end of the World War One and following conclusion of Sykes-Picot agreement. In this agreement, the borders between different races and tribes has been specified regardless of their historical, ethnic, religion and racial backgrounds and only on the ground of the interest of countries won the War and participated in writing the contract.

The border conflict between the United Arab Emirates, Oman and the Saudi Arabia over ownership of Al-Hadid oilfield or disagreement between the United Arab Emirates and The Saudi Arabia on governance of al-Buraimi, Khawr al Udayd and Sabrkheh Mati are some examples to mention.

Additionally, there is border conflict between The Saudi Arabia and Yemen over occupied provinces of Asir, Najran and Jizan in Yemen with total area corresponding to that of the Syria. The Saudi Arabia always tries to exert dominance over some areas of Yemen situated besides The Arabian Sea or Bab-el-Mandeb Strait. In 1926, Abdul Aziz bin Saud occupied three provinces of the Yemen and all his sons have follow his policy to extent their dominance over either total or some areas of the Yemen since then. The Saudi Arabia's government support for this aggressive policy is ongoing and being manifested through their recent assault to the Yemen.

There has been also border conflict between the Iraqis and the Kuwaitis during which the former made serious attempts to gain dominance over Warbah and Bubiyan islands since 1969 to 1990 . Attacks carried out by the Iraqis against Kuwait in the March 1973, September 1976, and early 1977 can provide more examples of such a border conflict between the two countries. These conflicted resulted in the Iraqi invasion of Kuwait in 1990.

There is either conflict between Iran and its other two Arab neighbors, namely the Iraq and the United Arab Emirates.

To give more examples of the border conflicts between the Middle East countries we can mention the ones between the Saudi Arabia and Qatar, The Saudi Arabia and Kuwait over Um Al Moradem, Qaroh islands, The Saudi Arabia and Oman over Al-Hadid oilfield and border conflict between The Syria and Turkey on Hatay Province and so on.

There are more than 20 cases of the border conflicts only between the Arab countries in this region.

In addition, there have been several conflicts arisen from the border conflict in the Middle East, to name some important ones are the Iran-Iraq war for specifying the borderline of Arvand Rud given by Sadam Hussein as reason to start the war against Iran or Iraq attack on Kuwait and the Saudi Arabia's invasion of Yemen as the newest one.

In general, it can be stated that there is not any country in the Middle East having never involved in border conflict with its neighbors. As the result, the region has experienced a security decline as well as increased animosity between the local countries. 


\section{Schism Conflicts and Misconception of Religious Principles}

The Middle East is the origin of three major monotheistic religions, namely Judaism, Christianity and Islam. Muslims make the largest population group in the Middle East. Most Jewish live in the North occupied Palestine and some, also, live in Iran, Tunisia, Syria, Morocco and Egypt. Christians reside in Lebanon, Syria, Egypt and Iraq.

Despite the similarity in their origin, there is obvious disagreement between the sects of these religions and each of which know themselves as rightful while others as unlawful and this inter-religious schisms have turned into wide intra-religious schism as well.

For instance, there are polarities even between Jews living in the Palestine. The Jews division into Zionist and Post-Zionists points out a type of political-social divergence in their society. While, religious versus Secular Jews are other classifications brought about cultural-religious gap between the Jews. And finally conflict between subgroups of Ashkenazic and Sephardic Jews has created further split within the Jews community.

There are growing disagreements between Shia and Sunni Muslims as well. Moreover, the existence of an ideological gap in the Central Asia has given rise to spread of all popular ideologies, and Wahhabi in particular in this region over the recent years which activity fighting with two other courses of thoughts that are Western democracy and Iranian Islamic Revolution.

Another disagreement to be mentioned here is Salfiat point of view based on its jihadi doctrine the Shias and Sufis are not considered as Muslims and must be put down. The jihadi ideology of this group inspired many armed group like Al-Qaeda in the early $21^{\text {st }}$ century. Such groups reject views of the practical Salfiat (traditional Salfiat) and recognize violence as the only way to defend Islam against the Western attacks.

Misconception of the religious principles is believed to be one the most important factors contributing to growth of the fundamentalism in the Middle East and Africa. Intellectual leaders of groups of this sort defy any signs of modernization, which are not generally in conflict with intellectual concepts of Islam, by arguing that they try to revive basic principles of Islam. Objection to women's education and opposition to followers of other Islamic groups and other religions are the most noticeable examples of such misinterpretation of religious concepts. Given the wide religious disparity and the disagreements between these major religions, the intra-religion conflicts and subjective and biased interpretation of the leaders of each group trying to explain the religious concepts according to one's own interest; it is no surprise to see such an ever-growing profound disagreement and animosity between the countries in the region.

\section{Ethnic Conflicts and Ethnic Diversity}

Population of the Middle East is generally a mixture of different races, namely Arabs, Turks, Pars, Kurds, Armenians and Berbers. Many small and big countries had been established with artificial and unreal borders following the dissolution of the Ottoman Empire. Specification of these borders had been in a way that they usually went across different tribes and races and, consequently, dividing these human groups into two or more subgroups. For example, wide regions separated from Iran during Safavid-Ottoman war is now located in the Turkey, Iraq and Syria which will be always a subject to conflict for sure.

Taking a careful look at countries, in which bases are provided for growth and activation of extremism, it is revealed that they are countries with wide diversity of religions and ethnics. Of course it must be mentioned that religious and ethnic diversity cannot simply lead to rise of fundamentalism, but there are other factors, like poverty and economic and cultural underdevelopment, paving the way for growth and spread of these groups.

For example, Iraq can be divided into three different regions in terms of sociocultural structures. Sunnis are in central areas, Kurds in the North and Shias in the South, each of which has their particular sociocultural divisions. Moreover, there are small ethnic groups with totally different cultures and ideologies, namely Turkamen, Ashurs and Yazidis. Therefore, though the presence of the U.S. army has provided strong motivation for entrance of foreign mercenary gangs into the Iraq, the principal factor helping the Al-Qaeda to organize its members and force its influence is the growing gaps and local conflicts between different groups in Iraq and, indeed, the opposition and conflicts made by Sunnis against other groups and political trends. Al-Qaeda has been crucial in radicalization of atmosphere of Iraq and fueling sectarian violence between Sunnis and Shias. Such groups have tried to capitalize on local sociopolitical discords in the Iraq to increase national insecurity and, in turn, deteriorating the Iraqi government as well as American forces.

\section{Structural Underdevelopment of the Middle East Countries}

The occurrence of two world wars and many other crazy acts done by human beings have made the Western 
European leaders believed that reforming old and outdated structures, institutions and standards are essential for their security. Internal Power (high-level of education, individual's high purchasing power, accessibility to health care services, interaction between norms, diversity in the media industries, protecting political and civil rights within the framework of rules and accepting the principle of people's legal priority to that of government) would lay the foundation for forming the structure of power.

Political security guarantees stability of political structure and organization and gives legitimacy and immunity to the political structure. Economic security involves free access to resources and funds and foreign markets. Social identity security is capacity of society in keeping its identity untouched from very real or likely threats and shifting situations. Nevertheless, occurrence of many coups and revolutions and existence of authoritarian states and dictatorship in the Middle East have presented grave structural problems. Underdevelopment and weak sociopolitical structure of the regional countries are easily noticeable in their economy, culture and social problems.

Arab states of the Persian Gulf, also, experience sociopolitical and structural problems and difficulties. This underdevelopment has prepared the way for foreign players to exert their influence into the region.

Following the $11^{\text {th }}$ September, the American strategists came to a conclusion that sociopolitical and economic incapacity of the regional countries is the reason lies behind the growth of terrorism in the Middle East. Given this point of view some states of the Persian Gulf and the Middle East cause worry due to their inefficient economic structures and limited economic progress and inability to attract foreign investment, all of which, in turn, decrease amount of invested funds in their national economies. The Middle East states enjoy large oil reserves and run a single product economy. And while rate of unemployment is soaring high in these countries, they are dependent on foreign workforce owing to insufficient scientific and technical educations.

Finally, all countries (Afghanistan, Pakistan, Iraq, Syria) chosen by the extremists to do their terrorist activates share similar characteristic, i.e. political instability and weakness. Most of these countries have been hit by crisis regarding their legitimacy and political stability that opened the way for foundation and activities of the fundamentalists.

\section{Arm and Security Race in the Middle East}

John Herz uses the term "security dilemma" to describe situation wherein governments compete with each other to have the best armed forces as they cannot trust in each other's intentions and, as the result, they get into a vicious cycle. Those countries heavily arm themselves to tighten up their securities feel less secure and, therefore, purchasing more weapons, and since equipment protecting a party's security is seen as a threat to the other party, countries respond to such threats by arming themselves as well. And this theory is really in practice in the Middle East. The regional countries have become entangled in a never ending competition to increase their amount of military equipment as they always feel threatened by their neighbors and these sorts of activities, in turn, will arouse their neighbors feeling of insecurity which makes them expanding their military capability as well.

There are three factors recognized in international system contributing to provoking fear between the states: 1) lack of a central institution at top level of the states to protect them against each other, 2) the fact that all states always have some sort of aggressive tendencies, 3) the states are always doubtful about intentions and purposes of other parties.

The Middle East countries possess the highest record for purchasing military equipment in the world. This fact is significant in insecurity of the region, and in this way the Middle east can not only experience peace but also may face greater increase in insecurity if such a trend is not stopped in the future.

According to recent news reported by the American magazine, "Economist Intelligence Unit", more than 10 states in the Middle East spend more than one billion USD on their defensive plans in the current year (the Saudi Arabia, Israel, Algeria, United Arab Emirates, Syria, Oman, Qatar, Iran, Kuwait, Morocco, Egypt.

The Saudi Arabia surpassed the U.K. on the list prepared by the London International Institute for Strategic Studies in 2013 arranging countries based on budgets they spent on military equipment and sat on fourth place. The result of this report could create the security dilemma and this sense of insecurity in anarchistic system may lead to even tighter arm race and purchase of more military facilities by the regional countries which, in turn, convey deeper sense of insecurity and intensify security race in the Middle East. Therefore, it is fairly predictable to observe chaos and long wars of erosion between the local states and militia in a region like the Middle East wherein the sense of security is tremendous and huge budgets set to purchase armament. The regional countries, in such a situation, show no respect to local affairs and rights of the other states and, 
consequently, have no hesitation to frequently interfere in their local affairs which will produce irrevocable results and deep and ever-lasting conflicts between people in this region.

For example, Riyadh has allocated more than 2 billion USD to support partitioning of the Yemen. The CIA also reveals that the Saudi Arabia has hired 12 MiG-29 fighters with Russian pilots to back the south rebels in the Yemen civil war.

The national security is the most decisive advantages of countries in international anarchistic and self-supporting system. Military and intelligence nature of the Israel besides its specific location surrounded by the Arab states none of which recognize it as a sovereign nation have given so great importance and high priority to military security in the national security of this regime that Israel, relying on its military power, fought 6 wars against its Arabs neighbors for protecting its security and removing military threats. The military budget of Israel is estimated to be 11 billion USD equal to $15 \%$ of its gross national product (GNP). Israel spent approximately 2.3 billion USD in the 33-day war with Lebanon Hezbollah.

The above-mentioned factors are the most important ones contributing to the escalation of sense of insecurity, growth of militarism and, consequently, violence and fundamentalism in the Middle East. Though there are many other factors effective in this regard, we only mention the most crucial ones here. The external factors in supporting and developing the terrorism and fundamentalism in the Middle East, and the role of the U.S. in particular will be brought up into the discussion in the following section.

\section{Foreign Factors}

"Mutual dependence", in its current definition, refers to a situation wherein the occurrence of any event anywhere around the world is effective on other things elsewhere. To describe mutual dependence as something intensive and to be intensified by force means that events, happened in any given place, can quickly exercise their influences on remote areas. Taking or producing such an effect is directly related to power and political, cultural, economic and military structure of countries. Therefore, it could be stated that a country like the U.S., enjoying high level of military and structural power, is able of exercising the greatest influence on countries with flimsy sociopolitical structures. As mentioned before, the Middle East states possess extremely shaky sociopolitical structures that make them fairly vulnerable to intervention by big powers, e.g. the U.S., however:

American theorists and strategists suggest their politicians and decision-making system to be actively involved in events of the world beyond the American borders if they want to maintain the U.S. leadership in making international policies and organizing and managing and controlling changes in the future of the world; to put it differently, they propose that the country should not return back to the policy of isolation or introspection, but to develop and pursue the policy of intervention especially in geopolitical and economically important regions to guarantee their benefits as well as leadership position. Employing interventionist policy in geopolitical and economically important regions, through considerable potentials of the U.S. for exploiting on the shaky sociopolitical structures and deeply-rooted problems and weakness in the Middle East countries, can play so great and effective role in creating and controlling the regional trends that it is hard to be overlooked by American officials. Therefore in this section we are going to study the role of the U.S. in emergence of terrorism in the Middle East.

Critics to Afghanistan Bombardment argue that the terrorism is rooted in the serious complaints and dissatisfaction from the U.S. and it is necessity to address such complaints, which are not so hard to recognized, to cease the terrorism in this region: deployment of the U.S. military forces in the Saudi Arabia wherein the holiest Muslim places are located, imposing sanctions against Iraq for many years resulted in death of hundreds of Iraqi children according to reports released by the U.N., the U.S. solid support of the Palestine invasion and allocation of billions of dollars for backing Israel [30]. Given what was mentioned, we categorize foreign factors into four groups: economic policies, dichotomy between policy and administration, military policies and Israel. We are going to talk about each category in detail.

\section{Economic Policies}

Economically, little dependence of the U.S. means that the Americans are so unlikely to lose their commercial partners and bearing a great cost as the result of such a loss. Other countries are much more dependent on the U.S. and if they break their economic and commercial ties with the U.S., they will more likely to suffer from such a loss. Taking the given points into account, the long-term sanctions against the U.S. could produce reverse effects on the economy of countries. The U.S. can manage to survive without seeking help from the rest of the world, but it is not vice versa. This fact demonstrates the Middle East dependence on the U.S. to be able to survive in the international markets and sustain their economic growth while the U.S. is free of such a 
considerable degree of reliance, given its great economic power, and, therefore, could formulate its polices open-handedly. Other downsides of the Middle East economy are that they are single product countries and highly dependent on their oil-export incomes to run their economy which makes them so vulnerable to pressure of more powerful rivals.

Posing economic sanction is one the U.S. strategies to pursue its objectives both in the Latin America and other regions, and the Middle East in particular. These sanctions have usually enforced against economically-weak countries, to give some example:

The sanctions enforced against the Iraqis by the U.N. and the U.S. leading to the death of hundreds of children according to the reports published by the U.N. Implementing such polices have stirred up hatred among the people of these regions.

These sanctions bring about serious and deteriorating effects on economy and social statues of the weak countries in the Middle East, and today we can see how the fundamentalist groups taking advantage of the hatred and animosity aroused between the local people as the result of such sanctions.

The U.S. placed an embargo on export of foodstuff and medical and hospital supplies to Cuba and Iraq. In 1996 during a 60-minute TV show, Madeleine Albright, the ex-representative of the United States in the U.N., was questioned on the report as" Is the sanction against Iraq worth the death of half a million children, which was more than Hiroshima casualty?".

It seems that the U.S. government is heedless about effects of its military as well as punitive and zero-tolerance policies on countries around the world that are rage and dissatisfaction among people, and can simply respond to the violence aroused as the result of their own harsh measures through employing greater violence.

\section{Dichotomy between Policy and Administration}

An acute observer should not ignore the fact that there is a great different between the U.S. words and deeds. Indeed, other countries' policy makers have been always interested in examining the Americans foreign policy. For instance, as Carr mentioned many years ago in 1939, "European governments know English speakers as masters in cloaking their selfish interests in notion of "public interest" and remind that this sort of hypocrisy is the very characteristic of Anglo-Saxon mind.

The U.S. has come into the Middle East broadcasting beautiful propagandas such as fight against terrorism, freedom and liberalism, political and economic growth, prevention of the further proliferation of weapons of mass destruction, promotion of the regional stability, democratization of the local states and protection of human rights. The U.S. justifies its presence in the Middle East by democratizing the region and claiming the human rights. While, the Saudi Arabia, one the most significant partners of the U.S. in the region, runs an absolute monarchy government with the least freedom, human rights and democracy.

The U.S. broadcast the propaganda of democratizing the Middle East states while turn a blind eye at non-democratic governments for preserving its stability, within the framework of its national interest, in the region.

Referring to the Americans intervention in the region, Roland Dumas, the ex-foreign minister of the France government, states that: "democratization is only to justify the U.S. intervention in the Middle East".

Despite the Americans humanitarian and moral gestures, e.g. Madeleine Albright visit to Pakistan and meeting Afghani women in death camp, they, in fact, had been careless about events occurred in time of Taliban dominance on Kabul and their barbaric acts and clear transgression of human rights, and women rights in particular. And such negligence had had little accordance with what they said before. They justify attacks on a country like Iraq by freedom and human rights, on one hand, and turn a blind eye at violation of human rights and lack of freedom in a country like Afghanistan on the other hand.

Though the U.S. and the U.K have played a key role in formation of Al-Qaeda, they further used $11^{\text {th }}$ September as reason to put the Al-Qaeda in list of Terrorist groups and by doing so they have not only legitimated their physical and military presence in the Afghanistan and the region but also paved the way for their strategic presence and further attacks on the Iraq. Three years before the $11^{\text {th }}$ September disaster, Robert Cowman, an ex-colonel in the U.S. Air Force, wrote in an article on root causes of the terrorism: world does not hate us as we have democracy and respect freedom and the human rights. We are hated since our government withholds such elevated standards from the people living in third world countries while our multinational corporations exploiting their resources. The seed of hatred we sowed have been growing as terrorism and hurts us now. We must invest in their infrastructures to be able to draw upon their oil reserves, not to send our children to kill the 
Arabs.

It perfectly shows why the local people hate the U.S. and why politicians in the Middle East have no trust in contradictory messages sent by the Americans.

Criticizing war-mongering policies employed by the U.S., Howard Zinn, the distinguished professor of political science in the University of Boston, suggests that: history of the U.S. interventionist policies indicates that dismantling political systems of other countries with the reason of democratization and freedom prepares the way for the U.S. to exert its own dominance over them. It is obvious that, today, Iraq is an occupied country rather than a free. It is outrageous to free Iraq from Saddam Hussein hand, but getting our hands on it instead.

\section{Military Policies}

The security is crucial in the anarchistic situation.

As mentioned in the previous section, deteriorating security and armed conflicts will promote arm trades in the Middle East and North Africa which, in turn, leading to reproduction of the security dilemma in this region. It causes a vicious cycle of the security dilemma and arm race.

An article written the New York Time in the autumn 2000 revealed that the U.S. sold armaments worth more than 11 billion USD that is equal to one-third of all weapons sold across the globe at that given year. The striking fact was that two-third of these armaments were sold to economically-poor countries, mostly including the Middle East states.

As predicted by Eisenhower, ex-president of the U.S., hefty military budgets have been approved yearly by the majority of Democrat and Republican voters in the United States Congress in the post-World War Two era during the presidency of Truman to Reagan and Bush. This happens while there is no justification for increased military budget and massive military expenditure after the end of the cold war.

September 11 attacks of terrorism on the Twin Towers gave the U.S. a good excuse for attacking Afghanistan, though as believed by many political scientists like Henry Kissinger, the attack was planned in advance, and the Afghanistan was invaded by NATO forces in no time. The reason given for presence of the U.S. and NATO forces in the Afghanistan and the region was to prevent expansion of Al-Qaeda and to preserve and maintain regional stability and security, though the outcome of this attack was totally adverse and Al-Qaeda still have significant presence in the region which makes local stability and security meaningless words. According to the report, represented in Afghan Parliament by supervisor of the Interior Ministry, only 9 out of 354 towns in the Country have been identified as the secure regions. This report shows the useless presence of the U.S. and NATO forces and even adverse result of such a presence produced in the security of the Afghanistan.

Since the U.S. attack on Iraq, pressure on Al-Qaeda has removed on the Pakistan and Afghanistan mountains and new opportunities provided for them in the Middle East.

The U.S. invasion of Iraq has allowed Al-Qaeda to reorganize and re-equip their forces and pursued their objectives. Moreover the invasion gives Al-Qaeda time to reorganize and re-equip their group in the Afghanistan.

It was after the U.S. attack on Iraq that different Salafi Jihadist militant groups emerged as rebel group and then the key actor in Iraq, opposing the new political trends and presence of the U.S. in the region. It, once more, indicates American wrong policies being observed from the very beginning of their invasion of Afghanistan and their military presence in the region by establishing ever-growing military bases in the Middle East and holy sites which, at least, allows the fundamentalist groups to take advantage of the presence of foreign forces in the region and arouse religious feelings and hatred of the local people. Another mistake was the U.S. attack on Iraq with the reason of fighting terrorism which, in turn, led to expansion of scope of war and development and spread of Al-Qaeda members across the world. And finally we quote part of the U.S. ex-present words to reveal the Americans wrong military policies on formation, development and evolution of terrorism in the Middle East.

As stated by Dwight D. Eisenhower: producing any weapon, launching any warship and firing any missile, at the end, mean stealing from those who are hungry but are not fed, those who are shaking from the cold but are not given clothes.

\section{Israel}

Maintaining Israel security, as the U.S. and the West Bridge in the Middle East, is regarded as irreversible strategy in the foreign policy of the West and no president and leader in the U.S. and Western states can ignore the importance of total security of the Israel. Therefore, any attack made by The U.S. and West against the Middle East states is to build a security belt for the Israel and to weaken those states believed to be a threat to the security of Israel. 
Military and intelligence nature of the Israel besides its specific location surrounded by the Arab states none of which recognize it as a sovereign nation have given so great importance and high priority to military security in the national security of this regime that Israel, relying on its military power, fought 6 wars against its Arabs neighbors for protecting its security and removing military threats.

Billions of dollars allocated by the U.S. to provide Israel with military aid to continue occupation of the Palestine is an effective factor contributing to growth of tension in the Middle East. The presence of Israel in the region and full backing of the U.S. create tension in the Middle East in different ways. The presence of this military and intelligence regime at place of the Muslim first Qiblah indicates a never-ending tension as Palestinian Muslims and all Muslims around the world cannot accept it. Another issue is about wide military and financial support the Israel receives from the U.S. which led to a sense of insecurity and an arm race among the local countries for prevising their securities. Another reason makes the Israel presence in the region as a potential tension is its neighboring countries all of which are Muslims with totally different ideologies to that Israel. This factor has generated frictions between them leading to growing sense of insecurity and fear in the Middle East and used as an excuse by fundamentalist groups to justify and legitimate their presence by fighting with Israel.

The annual budget of Israel is estimated to be 11 billion dollars which is equal to $15 \%$ of its GNP.

Israel spent approximately 2.3 billion USD in the 33-day war with Lebanon Hezbollah.

Wide destruction of economic and social infrastructures, massacre of civilians and displacement of about 1 million people are evidences reveal the heavy cost of war for Lebanon.

There are only 12 camps in Lebanon accommodating 400 thousands DPs most of them living in dire straits. And it causes the constant instability and growth of tension and terrorism in the region. These wide annihilations in the Lebanon and other countries like Syria open up ample opportunity for the fundamentalist to expand individually and geographically by attracting more recruits.

\section{Conclusion}

As mentioned in the sociopolitical analysis of the Middle East, this region possesses vast potentials for formation, development and growth of terrorist and anti-human activities. The mentioned local factors along with the foreign ones that are the U.S. intervention and the wrong polices employed by the American governments have increased the growth terrorism in the Middle East and made terrorism as a high important issue in the field of political science and international relationships. Though demonstrating its full commitment to the human rights and democracy, the U.S. history of insult to democracy and violation of the primary human rights in this region have been so great that it is hard to be documented. Undoubtedly, the American violation of the human rights, which was briefly discussed in this article, has played significant role in formation and emergence of terrorism in the Middle East.

\section{References}

Ablol Khani, A. (2007). Terrorism Analysis. Research Institute for International and Cultural Studies, p 35.

Asadi, A. K. (2009). Rise and Decline of Al-Qaeda. Rahbord Periodical, (51), 234-240.

Bahrami, M. (2010). the Role Actors in Afghanistan Revolution: a Complex Crisis. Deputy of Foreign Policy Research, 199.

Buzan, B. (1991). People, States and Fear: An Agenda for International Security in the Post-cold War Era (2nd ed.). Boulder Co, Lynne Reiner, pp 19-56.

Dehghani Firooz Abadi, S. J. (2010). Lebanon Asymmetric warfare and Israel national Security. Foreign Policy Periodical, (1), 58-82.

Faraji Raad, A. R., Darkhor, M., \& Sadati, S. M. (2011). Afghanistan New Geopolitics after the $11^{\text {th }}$ September and its Effects on Iranian National Security. Human Geography Scientific-Research Periodical, (2), 194.

Golkaran, J. (2007). Al-Qaede Gives Lebanon Crisis New Dimensions, No. 188.

Howard, Z. (2011). American History since 1942 to 2001 (translated by Mani Salehi Allameh). Tehran, Popular book.

Jafari Valdani, A. (2009). the Saudi Arabia Dream of Dominating Yemen. Political and International Approach, $40-48,58$.

Jafari Valdani, A. (2010). Iranian Seven Thousands Years of Dominance over Tunb and Abu Musa islands. Political Science Bulletin, (4), 13. 
Jafari Valdani, A. (2010). the Role of Iraqi Geopolitical bottlenecks in the Invasioin of Kuwait. Geopolitics Periodical, (3), 52.

Kent, W. (2013). Theory of International Policy (translated by Gholam Ali Changi Zadeh and Dariush Yosefi). Tehran, International Research and Education Center, p 289.

Kent, W. (2013). Theory of International Policy (translated by Gholam Ali Changi Zadeh and Dariush Yosefi). Tehran, International Research and Education Center, p 225, 254.

Khori Hata, P. (2003). Near East in History: A Five Thousand-Year Background. Tehran, p 16.

Khosravani, Gh. (2010). America and the Middle East: Strategies and Challenges. Research Institute for Strategic Information, p 27, 171.

Mearsheimer, J. (2014). Political Tragedy of the Great Powers (translated by Gholam Ali Changi Zadeh). Tehran, Office of International and Political Studies, p 3, 29.

Monfared, D. (2013). the Saudi Arabia, the Fourth biggest Weapon Buyer. Retrieved from blog.pankkere.com

Moslehi, M. (2007). Al-Qaeda in Afghanistan. Regional Research of the Islamic World Periodicals, (30), 6, 9.

Schid, A., \& Jongman, A. (1988). Political Terrorism: a New Guide to Actors, Authors, Database, Theories and Literature, Amsterdam, Holland Transaction Books, p 5.

Soleimani, R. (2007). Conceptual Confusion in Scientific and Political Discussion. Strategic Research Center Journal, (43), 189.

Yusef Al-Uyairi and the Making if a Revolutionary Salafi Praxis.

\section{Copyrights}

Copyright for this article is retained by the author(s), with first publication rights granted to the journal.

This is an open-access article distributed under the terms and conditions of the Creative Commons Attribution license (http://creativecommons.org/licenses/by/3.0/). 